\title{
Synthesis and Characterization of a Narrow-Bandgap Polymer Containing Alternating Cyclopentadithiophene and Diketo-Pyrrolo-Pyrrole Units for Solar Cell Applications
}

\author{
GUAN-YU CHEN, ${ }^{1}$ CHIEN-MING CHIANG, ${ }^{1}$ DHANANJAY KEKUDA, ${ }^{2}$ SHANG-CHE LAN, ${ }^{1}$ CHIH-WEI CHU, ${ }^{2,3}$ KUNG-HWA WEI $^{1 *}$ \\ ${ }^{1}$ Department of Materials Science and Engineering, National Chiao Tung University, Hsinchu 300, Taiwan \\ ${ }^{2}$ Research Center for Applied Sciences, Academia Sinica, Taipei 115, Taiwan \\ ${ }^{3}$ Department of Photonics, National Chiao Tung University, Hsinchu 300, Taiwan
}

Received 17 December 2009; accepted 11 January 2010

DOI: 10.1002/pola.23931

Published online in Wiley InterScience (www.interscience.wiley.com).

ABSTRACT: We have synthesized a narrow-bandgap conjugated polymer (PCTDPP) containing alternating cyclopentadithiophene (CT) and diketo-pyrrolo-pyrrole (DPP) units by Suzuki coupling. This PCTDPP exhibits a low band gap of $1.31 \mathrm{eV}$ and a broad absorption band from 350 to $1000 \mathrm{~nm}$, which allows it to absorb more available photons from sunlight. A bulk heterojunction polymer solar cell incorporating PCTDPP and $\mathrm{C}_{70}$ at a blend ratio of 1:3 exhibited a high short-circuit current of 10.87 $\mathrm{mA} / \mathrm{cm}^{2}$ and a power conversion efficiency of $2.27 \%$. (C) 2010 Wiley Periodicals, Inc. J Polym Sci Part A: Polym Chem 48: 1669-1675, 2010

KEYWORDS: conjugated polymers; copolymerization; diketopyrrolo-pyrrole; heteroatom-containing polymers; solar cell
INTRODUCTION The development of conjugated polymers that possess extended delocalized $\pi$-electron systems and can be used in organic optoelectronic devices has been an area of intense investigation, with many studies having focused on solar cell devices based on bulk heterojunctions (BHJ) of conjugated polymers. ${ }^{1-7}$ Polythiophene derivatives are among the most promising materials for solar cell applications because of their high light absorption and high electronic conductivity. For example, BHJ solar cell devices containing blends of regioregular poly(3-hexylthiophene) (rr-P3HT) as the donor and $[6,6]$-phenyl- $\mathrm{C}_{61}$-butyric acid methyl ester (PCBM) as the acceptor can exhibit power conversion efficiencies (PCEs) as high as $4-5 \%{ }^{8-16}$ Nevertheless, because the absorption band of rr-P3HT is located at wavelengths of less than $650 \mathrm{~nm}$, it can harvest only $22.4 \%$ of the available photons from sunlight. ${ }^{17}$ Hence, it remains a challenge to develop polymer materials that feature broader and longer wavelength absorptions to improve the PCEs of such devices.

There are two main approaches toward lowering the bandgaps of polymers. The first involves the introduction of electron donor (D) and acceptor (A) units into the polymer main chain; indeed, alternating such donor and acceptor moieties along a polymer backbone is an effective means of reducing the bandgaps of polymers through intrachain charge transfer. The second involves increasing the coplanarity of the polymeric structure, thereby decreasing the bandgap by increasing the degree of delocalization of the $\pi$ electrons. ${ }^{17}$
Many D-A conjugated polymers contain thiophene, ${ }^{18-20}$ fluorene, $^{21,22}$ carbazole, ${ }^{23-26}$ and cyclopentadithiophene ${ }^{27-29}$ units as donor units, whereas acceptor units are benzothiadiazole, $^{30,31}$ quinoxaline, $^{32,33}$ and thienopyrazine. ${ }^{34,35}$ For example, poly $\left[N-9^{\prime}\right.$-heptadecanyl-2,7-carbazole-alt-5,5- $\left(4^{\prime}, 7^{\prime}\right.$ di-2-thienyl-2', $1^{\prime}, 3^{\prime}$-benzothiadiazole)] (PCDTBT) possesses a band gap of $1.88 \mathrm{eV}$. BHJ solar cell fabricated with PCDTBT/ $\mathrm{PC}_{71} \mathrm{BM}$ can achieve a high PCE of $6.1 \%{ }^{24,36}$ Another case involves poly[2,6-(4,4-bis[2-ethylhexyl]-4H-cyclopenta[2,1b;3,4-b]dithiophene)-alt-4,7-(2,1,3-benzothiadiazole)] (PCPDTBT) that has a broad absorption ranging from 380 to $900 \mathrm{~nm}$ and a low band gap (1.40 eV). BHJ solar cells based on PCPDTBT/ $\mathrm{PC}_{71} \mathrm{BM}$ can achieve a $\mathrm{PCE}$ of $5.5 \%{ }^{29,37}$ One potential strategy for improving the efficiency further is to incorporate planar molecular structures into the polymer backbone. Cyclopentadithiophene (CT)-based polymers generally exhibit low bandgaps and high carrier mobilities because of their highly planar and rigid structures. ${ }^{37-39}$ Several narrow-bandgap polymers containing diketopyrrolopyrrole (DPP) units have also been applied in solar cells exhibiting good performance. $^{40-44}$ DPP units have planar, highly conjugated, lactam structures, which result in strong $\pi-\pi$ interactions and strong electron-withdrawing effects. ${ }^{45-47}$

In this study, we prepared an extended conjugated molecular structure in which CT moieties were incorporated into a polymeric main chain to increase the effective conjugation length of the system. Scheme 1 displays our synthetic routes 

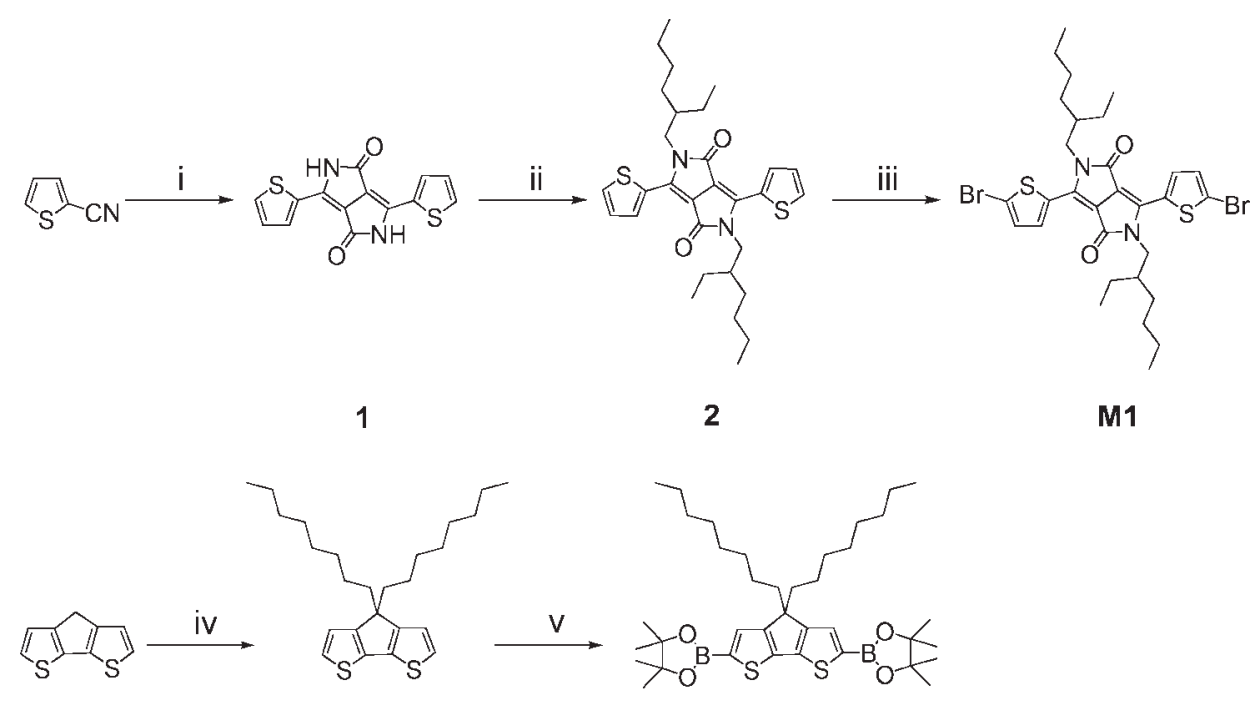

3

4
M2
SCHEME 1 Reagents and conditions: (i) dibutyl succinate, $\mathrm{Na}$, tert-amyl alcohol, $90{ }^{\circ} \mathrm{C}, 20 \mathrm{~h}$; (ii) 2-ethylhexyl bromide, DMF, $\mathrm{K}_{2} \mathrm{CO}_{3}$, $120{ }^{\circ} \mathrm{C}, 20 \mathrm{~h}$; (iii) $\mathrm{NBS}, \mathrm{CHCl}_{3}, \mathrm{rt}, 48$ h; (iv) 1-bromooctane, $\mathrm{KI}, \mathrm{KOH}$, DMSO, rt, overnight; (v) $n$-BuLi, $-78{ }^{\circ} \mathrm{C}, 1 \mathrm{~h}$; then 2-isopropoxy4,4,5,5-tetramethyl-1,3,2-dioxaborolane, rt, overnight. toward the planar CT and DPP moieties. We expected the presence of the CT moieties in the polymer backbone to lower the bandgap of the polymer. Scheme 2 displays the copolymerization of the CT and DPP units, performed using a versatile Suzuki cross-coupling reaction.

\section{EXPERIMENTAL}

\section{Materials}

Thiophene-2-carbonitrile, dibutyl succinate, 2-ethylhexyl bromide, $N$-bromosuccinimide (NBS), 1-bromooctane, 2-isopropoxy-4,4,5,5-tetramethyl-1,3,2-dioxaborolane, aliquat 336, tetrakis(triphenylphosphine)palladium(0), bromobenzene, and phenylboronic acid were purchased from Aldrich, Fluka, ACROS, and TCI. Common organic solvents were purchased from Tedia and J. T. Baker. Toluene was dried over calcium hydride; THF was dried over sodium and benzophenone. All other reagents were used as received from their commercial sources.

\section{Measurements and Characterization}

${ }^{1} \mathrm{H}$ and ${ }^{13} \mathrm{C}$ NMR spectra were recorded using a Varian Unity-300 NMR spectrometer. The number-average $\left(M_{\mathrm{n}}\right)$ and weight-average $\left(M_{\mathrm{w}}\right)$ molecular weights of PCTDPP were measured through gel permeation chromatography (GPC) using a Waters chromatography unit interfaced with a Waters 2414 differential refractometer. Three 5- $\mu \mathrm{m}$ Waters styragel columns were connected in series in decreasing order of pore size $(104,103$, and $102 \AA)$; THF, the eluent and standard polystyrene samples, were used for calibration. Differential scanning calorimetry (DSC) was performed using a Perkin-Elmer Pyris DSC1 instrument operated at a heating rate of $10{ }^{\circ} \mathrm{C} / \mathrm{min}$ under a $\mathrm{N}_{2}$ purge. Thermogravimetric analysis (TGA) of PCTDPP was performed using a Du Pont TGA 2950 instrument operated at a heating rate of $10{ }^{\circ} \mathrm{C} /$ min under a $\mathrm{N}_{2}$ purge. UV-vis absorption spectra were measured using an HP Agilent-8453 diode array spectrophotometer. Electrochemical cyclic voltammetry (CV) was performed using a BAS 100 electrochemical analyzer and solutions in acetonitrile containing $0.1 \mathrm{M}$ tetrabutylammonium hexafluorophosphate $\left(\mathrm{TBAPF}_{6}\right)$ as the electrolyte; the scan rate was $100 \mathrm{mV} / \mathrm{s}$. A glassy disk carbon electrode coated with a thin film of the polymer was used as the working electrode; a $\mathrm{Pt}$ wire was the counter electrode; and $\mathrm{Ag} / \mathrm{Ag}^{+}\left(0.01 \mathrm{M} \mathrm{AgNO}_{3}\right)$ was the reference electrode; ferrocene was the internal standard.

\section{Device Fabrication and Characterization of Solar Cells} Devices were in the configuration glass/indium tin oxide (ITO)/poly(3,4-ethylenedioxythiophene):poly(styrene sulfonate) (PEDOT:PSS)/PCTDPP:PCBM/Al. The active layers were prepared by dissolving PCTDPP and PCBM (2 wt \%) in 1,2-dichlorobenzene at blend ratios varying from $1: 1$ to $1: 4$.

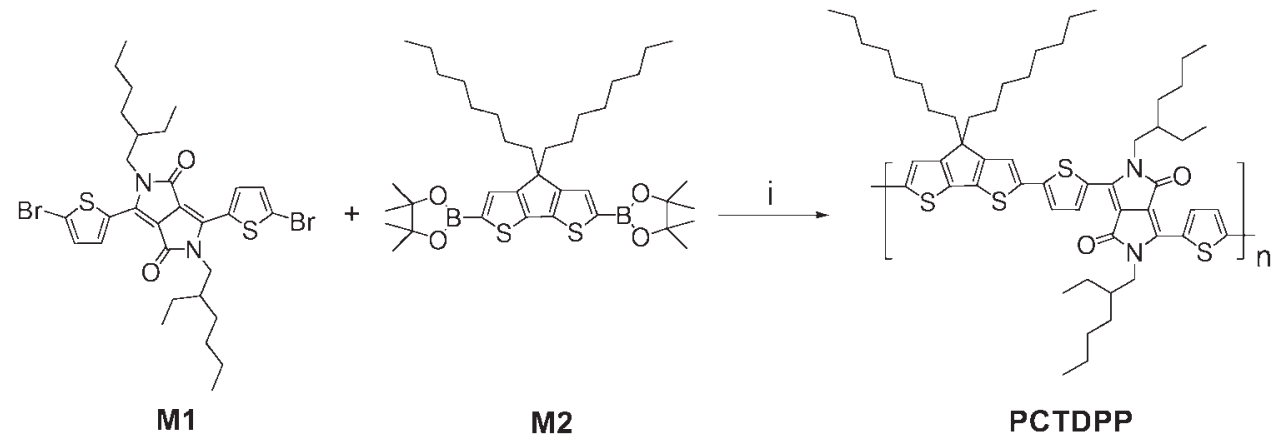

SCHEME 2 Reagents and conditions: (i) $\mathrm{Pd}\left(\mathrm{PPh}_{3}\right)_{4}, 2 \mathrm{M} \mathrm{K}_{2} \mathrm{CO}_{3(\mathrm{aq}) \text {, }}$ toluene, $100{ }^{\circ} \mathrm{C}, 8 \mathrm{~h}$. 
TABLE 1 Molecular Weights and Thermal Properties of PCTDPP

\begin{tabular}{llllll}
\hline & $M_{\mathrm{n}}$ & $M_{\mathrm{w}}$ & PDI & $T_{\mathrm{g}}\left({ }^{\circ} \mathrm{C}\right)$ & $T_{\mathrm{d}}\left({ }^{\circ} \mathrm{C}\right)^{\mathrm{a}}$ \\
PCTDPP & 18,000 & 38,160 & 2.12 & 150 & 385
\end{tabular}

a Temperature at which 5 wt \% loss of the initial weight occurred.

After dissolving the components, the resultant solution was spin-coated onto ITO/PEDOT:PSS substrates at $1500 \mathrm{rpm}$ for $60 \mathrm{~s}$. The films were then left to dry at room temperature. No additional thermal treatment was applied to the active layers. The films were subjected to cathode deposition through a shadow mask to result in a device area of 0.12 $\mathrm{cm}^{2}$. Aluminum was used as the cathode. The devices were characterized for their photoresponse using an Agilent 4156 semiconductor parameter analyzer, under AM 1.5 radiation $\left(100 \mathrm{~mW} / \mathrm{cm}^{2}\right)$. The spectral mismatch factor was calculated by comparison of the solar simulator spectrum and the AM 1.5 spectrum at room temperature.

\section{Synthetic Procedures}

4H-Cyclopenta[2,1-b:3,4-b'] dithiophene (3) was synthesized according to literature procedures. ${ }^{48-51}$ The synthetic procedures for the preparation of the monomers M1 and M2 and the copolymer PCTDDP are described in Schemes 1 and 2.

\section{3,6-Di(thiophen-2-yl)pyrrolo[3,4-c]pyrrole-1,4(2H,5H)- dione (1)}

A mixture of $\mathrm{Na}(0.490 \mathrm{~g}, 21.3 \mathrm{mmol})$ and a catalytic amount of $\mathrm{FeCl}_{3}$ was dissolved in tert-amyl alcohol $(10 \mathrm{~mL})$ by heating at $90{ }^{\circ} \mathrm{C}$ for $2 \mathrm{~h}$. After cooling to $50{ }^{\circ} \mathrm{C}$, thiophene-2-carbonitrile $(0.990 \mathrm{~mL}, 10.6 \mathrm{mmol})$ was added and then the mixture was again heated at $90^{\circ} \mathrm{C}$. A solution of dibutyl succinate (1.00 $\mathrm{mL}, 4.26 \mathrm{mmol})$ in tert-amyl alcohol ( $5 \mathrm{~mL}$ ) was added dropwise over $2 \mathrm{~h}$ and then the mixture was maintained at $90{ }^{\circ} \mathrm{C}$ for $20 \mathrm{~h}$. After cooling to $50{ }^{\circ} \mathrm{C}$, glacial $\mathrm{AcOH}$ was added and then the mixture was heated under reflux for $10 \mathrm{~min}$ before being filtered. The residue was washed several times with hot $\mathrm{MeOH}$ and water, and then the solid was dried under vacuum to yield 1 (0.8 g, $63 \%$ ). This compound was used directly in the next step without purification.

\section{2,5-Bis(2-ethylhexyl)-3,6-di(thiophen-2-yl)pyrrolo[3,4-c] pyrrole-1,4(2H,5H)-dione (2)}

A solution of 2-ethylhexyl bromide ( $4.89 \mathrm{~mL}, 27.5 \mathrm{mmol}$ ) in DMF (30 mL) was added dropwise to a mixture of Compound 1 (2.50 g, $8.33 \mathrm{mmol}), \mathrm{K}_{2} \mathrm{CO}_{3}$ (3.83 g, $27.8 \mathrm{mmol}$ ), and 18-crown-6 (0.25 g, $0.95 \mathrm{mmol})$ in DMF (50 mL) at 120 ${ }^{\circ} \mathrm{C}$ and then the mixture was maintained at $120{ }^{\circ} \mathrm{C}$ overnight. After cooling to room temperature and filtering, the product was dissolved in $\mathrm{CHCl}_{3}$ washed with water $(3 \times 100 \mathrm{~mL})$, and then dried $\left(\mathrm{MgSO}_{4}\right)$. The solvent was evaporated under reduced pressure and the crude product was purified through chromatography $\left(\mathrm{SiO}_{2}\right)$ to yield $2(2.05 \mathrm{~g}, 47 \%)$.

${ }^{1} \mathrm{H}$ NMR (300 MHz, $\mathrm{CDCl}_{3}$ ): $\delta 8.86(\mathrm{dd}, J=1.2,3.9 \mathrm{~Hz}, 2 \mathrm{H}$ ), 7.60 (dd, $J=1.2,4.8 \mathrm{~Hz}, 2 \mathrm{H}), 7.24(\mathrm{dd}, J=1.2,4.8 \mathrm{~Hz}, 2 \mathrm{H}$ ),
3.91-3.95 (m, 4H), 1.82-1.84 (m, 2H), 1.21-1.38 (m, 16H), 0.76-1.20 (m, 12H). ${ }^{13} \mathrm{C}$ NMR (75 MHz, $\left.\mathrm{CDCl}_{3}\right): \delta$ 161.7, $140.4,135.2,130.5,129.8,128.4,107.9,45.8,39.1,30.2$, $28.3,23.5,23.0,14.0,10.5$.

\section{3,6-Bis(5-bromothiophen-2-yl)-2,5-bis(2-ethylhexyl) pyrrolo[3,4-c]pyrrole-1,4(2H,5H)-dione (M1)}

NBS (0.36 g, $2.0 \mathrm{mmol})$ was added to a solution of $2(0.50 \mathrm{~g}$, $0.95 \mathrm{mmol})$ in $\mathrm{CHCl}_{3}(30 \mathrm{~mL})$ in a two-neck round-bottom flask covered with $\mathrm{Al}$ foil. After stirring at room temperature for $48 \mathrm{~h}$, the reaction mixture was poured into water (100 $\mathrm{mL})$ and extracted with $\mathrm{CHCl}_{3}(3 \times 100 \mathrm{~mL})$. The organic layer was dried $\left(\mathrm{MgSO}_{4}\right)$ and the solvent was evaporated under reduced pressure. The crude product was purified chromatographically $\left(\mathrm{SiO}_{2}\right)$ to yield Compound M1 (0.34 g, $53 \%)$.

${ }^{1} \mathrm{H}$ NMR (300 MHz, $\mathrm{CDCl}_{3}$ ): $\delta 8.62(\mathrm{~d}, J=4.5 \mathrm{~Hz}, 2 \mathrm{H}), 7.19$ (d, $J=4.5 \mathrm{~Hz}, 2 \mathrm{H}), 3.91-3.95(\mathrm{~m}, 4 \mathrm{H}), 1.79-1.80(\mathrm{~m}, 2 \mathrm{H})$, 1.20-1.37 (m, 16H), 0.82-0.88 (m, 12H). ${ }^{13} \mathrm{C}$ NMR (75 MHz, $\left.\mathrm{CDCl}_{3}\right): \delta 161.4,139.4,135.4,131.4,131.1,119.0,108.0$, 46.0, 39.1, 30.1, 28.3, 23.5, 23.0, 14.0, 10.4. Anal. Calcd. for $\mathrm{C}_{30} \mathrm{H}_{38} \mathrm{Br}_{2} \mathrm{~N}_{2} \mathrm{O}_{2} \mathrm{~S}_{2}$ : C, 52.79; H, 5.61; N, 4.10. Found: C, 52.50; $\mathrm{H}, 5.34 ; \mathrm{N}, 3.77 \%$.

\section{4,4-Dioctylcyclopenta[2,1-b:3,4-b']dithiophene (4)}

$\mathrm{KOH}$ (3.14 g, $56.2 \mathrm{mmol}$ ) was added slowly to a mixture of $\mathbf{3}$ (2.00 g, $11.2 \mathrm{mmol}$ ), 1-bromooctane (8.67 g, $44.9 \mathrm{mmol}$ ), and $\mathrm{KI}(80 \mathrm{mg}, 0.48 \mathrm{mmol})$ in DMSO (55 mL) at $0{ }^{\circ} \mathrm{C}$. After stirring at room temperature overnight, the mixture was poured into water and extracted with hexane $(3 \times 100 \mathrm{~mL})$. The organic layer was dried $\left(\mathrm{MgSO}_{4}\right)$ and the solvent evaporated under reduced pressure. The crude product was purified chromatographically $\left(\mathrm{SiO}_{2}\right)$ to yield 4 (3.61 g, 80\%).

${ }^{1} \mathrm{H}$ NMR (300 MHz, $\mathrm{CDCl}_{3}$ ): $\delta 7.12(\mathrm{~d}, J=4.8 \mathrm{~Hz}, 2 \mathrm{H}), 6.91$ (d, $J=4.8 \mathrm{~Hz}, 2 \mathrm{H}), 1.77-1.86(\mathrm{~m}, 4 \mathrm{H}), 1.12-1.55(\mathrm{~m}, 20 \mathrm{H})$, 0.80-0.94 (m, 10H). ${ }^{13} \mathrm{C}$ NMR $\left(75 \mathrm{MHz}, \mathrm{CDCl}_{3}\right): \delta$ 158.1, $136.4,124.4,121.6,53.2,37.7,31.8,30.0,29.3,29.2,24.5$, 22.6, 14.1 .

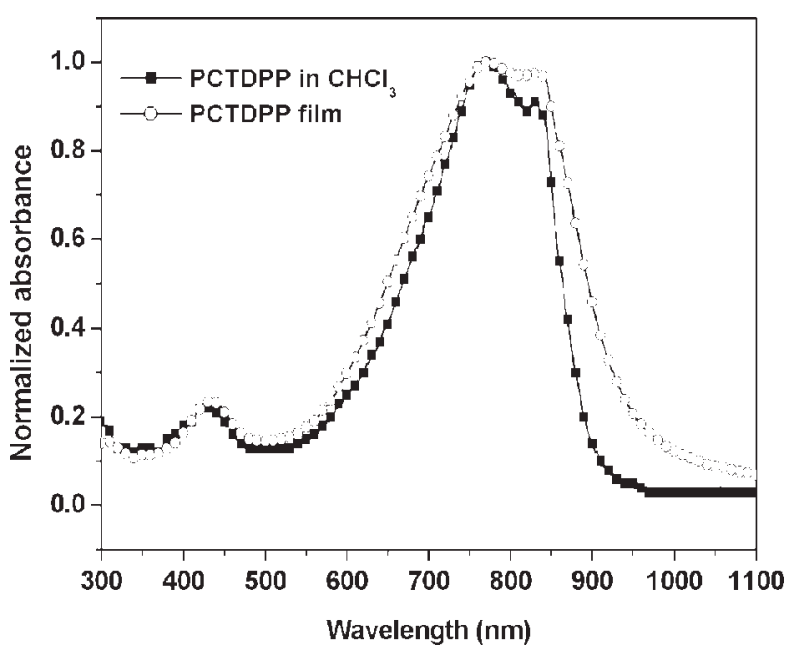

FIGURE 1 Normalized UV-vis absorption spectra of PCTDPP. 
TABLE 2 Optical and Electrochemical Properties of PCTDPP

\begin{tabular}{|c|c|c|c|c|c|c|c|c|}
\hline & $\lambda_{\max }(\mathrm{nm}) \mathrm{sol}$ & $\lambda_{\max }(\mathrm{nm})$ film & $E_{\mathrm{g}}^{\mathrm{opt}}(\mathrm{eV})^{\mathrm{a}}$ & $E_{\text {onset }}^{\text {ox }}(\mathrm{V})$ & $E_{\text {onset }}^{\text {red }}(\mathrm{V})$ & HOMO (eV) & LUMO (eV) & $E_{\mathrm{g}}^{\mathrm{ec}}(\mathrm{eV})^{\mathrm{b}}$ \\
\hline PCTDPP & 764 & 772 & 1.31 & 0.15 & -1.49 & -4.95 & -3.31 & 1.64 \\
\hline
\end{tabular}

\section{2,6-Bis(4,4,5,5-tetramethyl-1,3,2-dioxaborolan-2-yl)-4,4- dioctylcyclopenta[2,1-b:3,4-b']dithiophene (M2)}

$n$-Butyllithium (1.2 M, $8.72 \mathrm{~mL}, 10.5 \mathrm{mmol}$ ) was added dropwise to a solution of 4 (2.00 g, $4.98 \mathrm{mmol})$ in dry THF in a three-neck round-bottom flask cooled at $-78{ }^{\circ} \mathrm{C}$. After stirring at $-78{ }^{\circ} \mathrm{C}$ for $1 \mathrm{~h}$, the mixture was warmed to room temperature over a period of $3 \mathrm{~h}$. The reaction mixture was cooled to $-78{ }^{\circ} \mathrm{C}$ again and then 2 -isopropoxy-4,4,5,5-tetramethyl-1,3,2-dioxaborolane ( $4.10 \mathrm{~mL}, 19.9 \mathrm{mmol})$ was added in one portion. The solution was warmed to room temperature and stirred overnight before being poured into water and extracted with EtOAc $(3 \times 100 \mathrm{~mL})$. The organic layer was dried $\left(\mathrm{MgSO}_{4}\right)$ and the solvent evaporated under reduced pressure. The crude product was recrystallized (MeOH) to yield $\mathbf{M} 2$ (1.63 g, 50\%).

${ }^{1} \mathrm{H}$ NMR (300 MHz, $\mathrm{CDCl}_{3}$ ): $\delta 7.40(\mathrm{~s}, 2 \mathrm{H}), 1.78(\mathrm{~m}, 4 \mathrm{H}), 1.33$ (s, 24H), 1.09-1.27 (br, 20H), 0.80-0.90 (m, 10H). ${ }^{13} \mathrm{C}$ NMR $\left(75 \mathrm{MHz}_{\mathrm{CDCl}}\right.$ ) : $\delta 161.5,143.9,131.1,84.0,52.7,37.8,31.7$, 30.0, 29.3, 29.2, 24.7, 24.4, 22.6, 14.0. Anal. Calcd. for $\mathrm{C}_{37} \mathrm{H}_{60} \mathrm{~B}_{2} \mathrm{O}_{4} \mathrm{~S}_{2}$ : C, 67.89; $\mathrm{H}, 9.24$. Found: C, 67.70; H, 9.42\%.

\section{PCTDPP}

A mixture of $\mathbf{M} 1$ (100 mg, $0.150 \mathrm{mmol}$ ), M2 (96.1 mg, 0.150 mmol), aliquat 336 (ca. $20 \mathrm{mg}$ ), $\mathrm{K}_{2} \mathrm{CO}_{3(\mathrm{aq})}(2 \mathrm{M}, 1.41 \mathrm{~mL}$ ), and toluene $(2.82 \mathrm{~mL})$ was degassed at $60{ }^{\circ} \mathrm{C}$ for $10 \mathrm{~min}$. $\mathrm{Pd}\left(\mathrm{PPh}_{3}\right)_{4}$ was added to the mixture, which was then heated at $110{ }^{\circ} \mathrm{C}$ for $8 \mathrm{~h}$. Phenylboronic acid (49.9 mg, $0.301 \mathrm{mmol}$ ) was added and then the mixture was stirred $12 \mathrm{~h}$. Subsequently, bromobenzene $(0.03 \mathrm{~mL}, 0.301 \mathrm{mmol})$ was also added to the mixture, and the whole mixture was stirred for another $12 \mathrm{~h}$. The reaction mixture was poured into $\mathrm{MeOH}$ $(50 \mathrm{~mL})$ and filtered. The precipitated material was purified by washing with $\mathrm{MeOH}$, acetone, and hexane in a Soxhlet system. The solid residue was then dissolved in $\mathrm{CHCl}_{3}$ and filtered. The solution was added into $\mathrm{MeOH}$ and the pure polymer was collected by filtration ( $80 \mathrm{mg}, 57 \%$ ).

${ }^{1} \mathrm{H}$ NMR (300 MHz, $\left.\mathrm{CDCl}_{3}\right): \delta 8.86(\mathrm{br}, 2 \mathrm{H}), 7.15(\mathrm{br}, 2 \mathrm{H})$, 6.89-6.93 (m, br, 2H), 4.06 (br, 4H), 1.87 (br, 6H), 1.23 (br, 40H), 0.87 (br, 18H). ${ }^{13} \mathrm{C}$ NMR (75 MHz, $\mathrm{CDCl}_{3}$ ): $\delta$ 160.9, 159.6, 143.3, 138.2, 137.3, 127.6, 123.4, 118.3, 107.8, 54.5, $45.9,39.2,37.9,31.8,30.1,29.6,29.4,29.3,28.6,24.5,23.7$, 23.1, 22.6. 14.0, 10.6, 0.9. Anal. Calcd. for $\mathrm{C}_{55} \mathrm{H}_{74} \mathrm{~N}_{2} \mathrm{O}_{2} \mathrm{~S}_{4}$ : C, 71.53; H, 8.08; N, 3.03. Found: C, 72.08; H, 7.89; N, 3.03\%.

\section{RESULTS AND DISCUSSION}

\section{Synthesis and Characterization}

Schemes 1 and 2 illustrate the synthetic routes that we used to prepare the monomers $\mathbf{M} 1$ and $\mathbf{M} 2$ and the copolymer PCTDPP. 3,6-Di(thiophen-2-yl)pyrrolo[3,4-c]pyrrole-1,4(2H,5H)- dione (1) was synthesized through the condensation of thiophene-2-carbonitrile and dibutyl succinate; without further purification, it was alkylated to provide Compound 2. M1 was obtained through subsequent bromination. 4H-Cyclopenta[2,1-b:3,4-b']dithiophene (3) was alkylated to provide Compound 4, which was successively treated with $n$-BuLi and 2-isopropoxy-4,4,5,5-tetramethyl-1,3,2-dioxaborolane to yield M2. Copolymerization of M1 and M2 through Suzuki crosscoupling provided the copolymer PCTDPP. The structures of the monomers and polymer were confirmed using ${ }^{1} \mathrm{H}$ and ${ }^{13} \mathrm{C}$ NMR spectroscopy and ELEM. ANAL. Table 1 lists the molecular weights, thermal decomposition temperature, and glass transition temperature of the polymer. The number-average weight $\left(M_{\mathrm{n}}\right)$ and polydispersity index (PDI) of polymer were $18,000 \mathrm{~g} / \mathrm{mol}$ and 2.12 , respectively. The polymer exhibited good thermal stability, with its $5 \%$ weight-loss temperature $\left(T_{\mathrm{d}}\right)$ at $385{ }^{\circ} \mathrm{C}$ and a high glass transition temperature $\left(T_{\mathrm{g}}\right)$ of $150{ }^{\circ} \mathrm{C}$. It was soluble in several chlorinated organic solvents, including $\mathrm{CHCl}_{3}$, chlorobenzene, and 1,2-dichlorobenzene.

\section{Optical Properties}

Figure 1 presents the absorption spectra of the polymers in dilute solution and as thin films; Table 2 summarizes the corresponding optical data. In dilute $\mathrm{CHCl}_{3}$, PCTDPP exhibited a small absorption band at 350-480 nm, which originated from the presence of CT moieties, and a large and broad absorption band between 500 and $900 \mathrm{~nm}$, which arose from intramolecular charge transfer (ICT) between the CT and DPP units. The absorption maximum of PCTDPP in $\mathrm{CHCl}_{3}$ was located at $764 \mathrm{~nm}$-a longer wavelength than that of a DPP-derivative polymer featuring a quaterthiophene

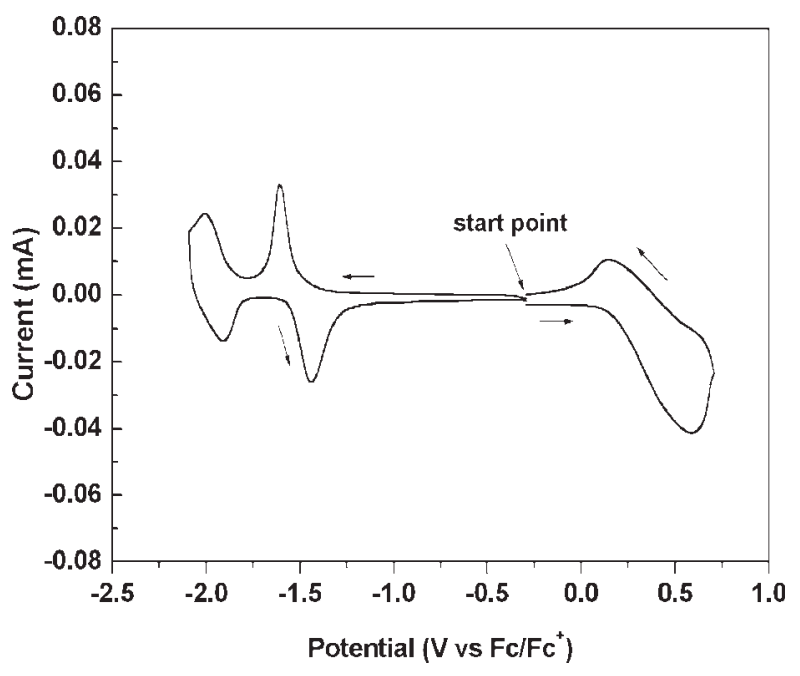

FIGURE 2 CV trace of PCTDPP. 

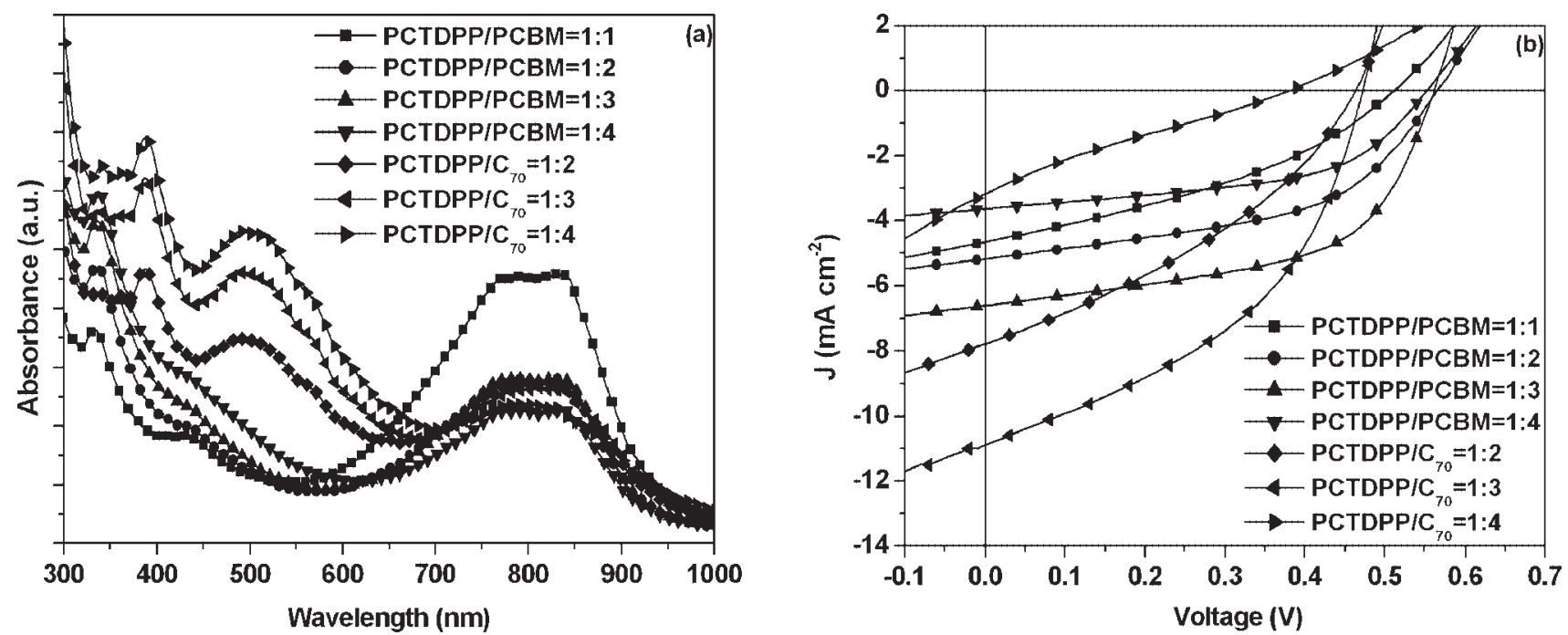

FIGURE 3 (a) Absorption spectra and (b) plots of illuminated current density $(J)$ with respect to applied voltage ( $V$ ) at various PCTDPP:PCBM and PCTDPP: $\mathrm{C}_{70}$ blend ratios.

segments as the donor $(650 \mathrm{~nm})^{41}$-because the presence of planar CT units in the polymer backbone increased the degree of coplanarity and provided a longer effective conjugation length. Relative to the solution absorption, the absorption spectrum of the polymer solid film was slightly broadened and exhibited a slight red shift, indicating that good intermolecular interactions and aggregation occurred in the solid-state again, as a result of the more-planar structure and strong polarity of the lactam moieties of the DPP units. The optical band gap $\left(E_{\mathrm{g}}^{\mathrm{opt}}\right)$, calculated from the absorption edge $(948 \mathrm{~nm})$ of the solid state film, was $1.31 \mathrm{eV}$. Because this polymer exhibited a broad absorption range (350-1000 $\mathrm{nm}$ ) and a low bandgap, we suspected that its good overlap with the solar spectrum would improve the degree of light harvesting and enhance the photocurrent of the devices.

\section{Electrochemical Properties}

$\mathrm{CV}$ is used widely to calculate the highest occupied molecular orbital (HOMO) and lowest unoccupied molecular orbital (LUMO) energy levels of polymers. We performed $\mathrm{CV}$ of a polymer film in acetonitrile containing $0.1 \mathrm{M} \mathrm{TBAPF}_{6}$ at a potential scan rate of $100 \mathrm{mV} / \mathrm{s}$. Figure 2 reveals that PCTDPP exhibited reversible reduction and oxidation processes, implying excellent electrochemical stability and high structural stability in charged states ${ }^{29,52,53}$; Table 2 summarizes the $\mathrm{CV}$ data. The onset oxidation and reduction potentials of PCTDPP were located at 0.15 and $-1.49 \mathrm{~V}$, respectively. The HOMO and LUMO energy levels of PCTDPP were -4.95 and $-3.31 \mathrm{eV}$, respectively, relative to ferrocene $(4.80$ $\mathrm{eV}$ below the vacuum) as the reference. ${ }^{26,44,54} \mathrm{We}$ assign the oxidation potential to oxidation of the CT units, because CT has a HOMO energy level of about $-5.1 \mathrm{eV}^{55}$ The low onset oxidation potential of PCTDPP confirms that the electron-donor ability of CT is strong, leading to a decreased bandgap relative to that of the DPP-derivative polymer incorporating quaterthiophene moieties as donor units. We attributed the reduction potential to the reduction of the DPP units. ${ }^{41}$ Low onset reduction potential of PCTDPP indicates that DPP possesses a strong electron-withdrawing ability due to the lactam structures. To overcome the exciton binding energy of the polymer and, thereby, transport electrons from the polymer to PCBM, the LUMO energy level of the polymer must be positioned above the LUMO energy level of PCBM by at least $0.3 \mathrm{eV}^{56,57}$ Gratifyingly, the LUMO energy level of PCTDPP suggests that electrons could be transported efficiently to PCBM; that is, the LUMO offset was $0.85 \mathrm{eV}$ relative to the LUMO energy level of PCBM $(-4.1 \mathrm{eV}) .{ }^{16,29}$ The fact that the electrochemical band gap $\left(E_{\mathrm{g}}^{\mathrm{ec}}\right)$ is higher than the optical band gap $\left(E_{\mathrm{g}}^{\mathrm{opt}}\right)$, may be due to the interface energy barrier presented between the polymer film and the electrode surface. ${ }^{31,58}$

\section{Photovoltaic Properties}

Figure 3 displays the absorption spectra of PCTDPP/PCBM blends and the photocurrents of devices having the structure ITO/PEDOT:PSS/PCTDPP:PCBM/Al under illumination at AM $1.5 \mathrm{G}$ and $100 \mathrm{~mW} / \mathrm{cm}^{2}$. The absorption spectra of the active layer exhibits absorptions at wavelengths in the range from 600 to $950 \mathrm{~nm}$, contributed by PCTDPP, and a small peak at about $350 \mathrm{~nm}$ resulting from the presence of PCBM. The

TABLE 3 Photovoltaic Properties of Polymer Solar Cells ${ }^{a}$

\begin{tabular}{lllll}
\hline $\begin{array}{l}\text { Weight Ratio } \\
\text { of Polymer to PCBM }\end{array}$ & $V_{\text {oc }}(\mathrm{V})$ & $\begin{array}{l}J_{\text {sc }} \\
\left(\mathrm{mA} / \mathrm{cm}^{2}\right)\end{array}$ & FF & PCE (\%) \\
PCTDPP:PCBM $=1: 1$ & 0.51 & 4.66 & 0.35 & 0.84 \\
PCTDPP:PCBM $=1: 2$ & 0.56 & 5.18 & 0.49 & 1.44 \\
PCTDPP:PCBM $=1: 3$ & 0.56 & 6.60 & 0.55 & 2.05 \\
PCTDPP:PCBM $=1: 4$ & 0.55 & 3.63 & 0.51 & 1.02 \\
PCTDPP: $C_{70}=1: 2$ & 0.46 & 7.84 & 0.34 & 1.21 \\
PCTDPP: $C_{70}=1: 3$ & 0.47 & 10.87 & 0.45 & 2.27 \\
PCTDPP: $C_{70}=1: 4$ & 0.37 & 3.17 & 0.21 & 0.24
\end{tabular}

a Polymer solar cell device structure: ITO/PEDOT:PSS/polymer:PCBM/AI. 


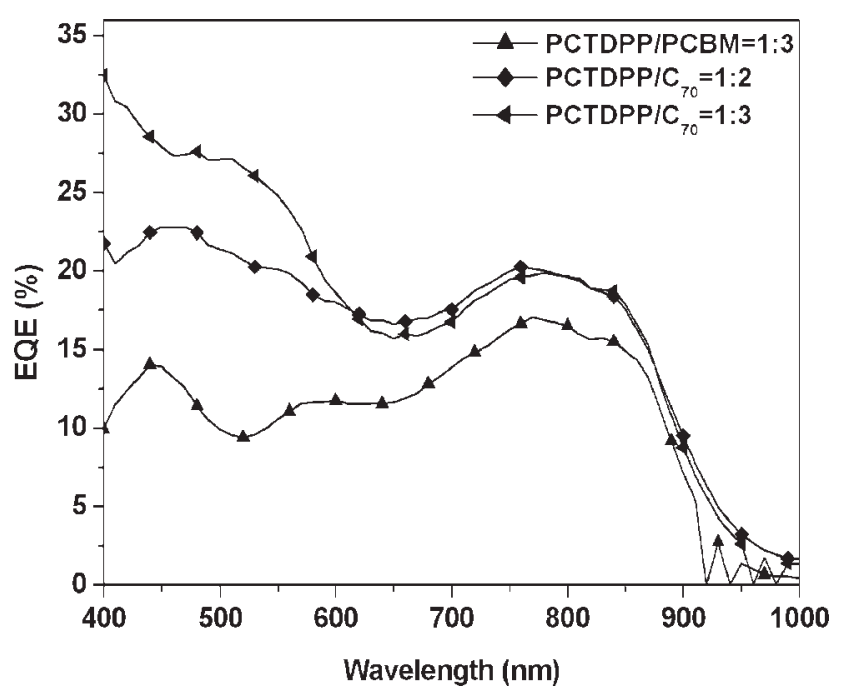

FIGURE 4 EQE spectra of the active layers $\left(\mathrm{PCTDPP} / \mathrm{C}_{70}\right)$ at blend ratios of 1:2, 1:3, and PCTDPP/PCBM at blend ratios of 1:3.

broad absorption band indicates that all available photons from sunlight have the potential to be absorbed by the active layer. Table 3 summarizes the performance of the devices. The short circuit current density $\left(U_{\mathrm{sc}}\right)$ increased significantly when we increased the amount of PCBM from a blend ratio of $1: 1-1: 3$. Increasing the loading weight ratio of PCBM to $1: 4$, however, decreased the short circuit current, presumably because of increased aggregation of $\mathrm{PCBM}^{59}$ For a blend ratio of $1: 3$, we obtained values of $J_{\mathrm{sc}}$ and PCE of $6.60 \mathrm{~mA} / \mathrm{cm}^{2}$ and $2.05 \%$, respectively. Next, we prepared solar cell devices incorporating $\mathrm{C}_{70}$ as a replacement for PCBM as the electron acceptor. Figure 3(a) reveals the presence of an absorption in the short wavelength range (ca. $500 \mathrm{~nm}$ ) that arose from $\mathrm{C}_{70}$, thereby leading an increased absorption intensity in the short wavelength range. ${ }^{60}$ Figure 4 displays the external quantum efficiency (EQE) curve of the device; its shape resembles that of the absorption spectra of the active layer, implying that all of the absorbed photons contributed to induce the photocurrent. The device exhibited a very broad response range, from 400 to $950 \mathrm{~nm}$, which allowed the active layer to absorb more available photons and enhance the photocurrent of the devices. A higher quantum efficiency at a wavelength of about $500 \mathrm{~nm}$ was obtained for the device incorporating a blend ratio of $1: 3$; that is, it was enhanced upon increasing the loading weight of $\mathrm{C}_{70}$. The short-circuit current also decreased when the weight ratio of PCTDPP to $\mathrm{C}_{70}$ is $1: 4$, which exhibiting a similar trend with that of PCTDPP/PCBM. Accordingly, the device based on PCTDPP: $C_{70}$ (1:3) exhibited the highest values of $J_{\text {sc }}$ and PCE-10.87 $\mathrm{mA} / \mathrm{cm}^{2}$ and $2.27 \%$, respectively.

\section{CONCLUSIONS}

We have used Suzuki coupling to synthesize a new polymer, PCTDPP, that features alternating CT and DPP units in its main chain. This polymer possesses a high glass transition temperature, good solubility, and high thermal stability.
Incorporating planar CT units in the polymer backbone lowered the bandgap of the copolymer to $1.31 \mathrm{eV}$ and broadened the absorption band to the range from 350 to 1000 $\mathrm{nm}$. The maximum values of $J_{\mathrm{sc}}$ and PCE $\left(10.87 \mathrm{~mA} / \mathrm{cm}^{2}\right.$ and $2.27 \%$, respectively) were obtained from the device incorporating PCTDPP and $\mathrm{C}_{70}$ at a blend ratio of 1:3.

The authors thank the National Science Council for financial support (NSC 98-2120M-009-006).

\section{REFERENCES AND NOTES}

1 Zhang, F.; Svensson, M.; Andersson, M. R.; Maggini, M.; Bucella, S.; Menna, E.; Inganäs, O. Adv Mater 2001, 13, 1871-1874.

2 Ramos, A. M.; Rispens, M. T.; van Duren, J. K. J.; Hummelen, J. C.; Janssen, R. A. J. J Am Chem Soc 2001, 123, 6714-6715.

3 Inganäs, O.; Svensson, M.; Zhang, F.; Gadisa, A.; Persson, N. K.; Wang, X.; Andersson, M. R. Appl Phys A 2004, 79, 31-35.

4 Huynh, W. U.; Dittmer, J. J.; Alivisatos, A. P. Science 2002, 295, 2425-2427.

5 Liu, J.; Kadnikova, E. N.; Liu, Y.; McGehee, M. D.; Fréchet, J. M. J. J Am Chem Soc 2004, 126, 9486-9487.

6 Zhang, S.; Guo, Y.; Fan, H.; Liu, Y.; Chen, H. Y.; Yang, G.; Zhan, X.; Liu, Y.; Li, Y.; Yang, Y. J Polym Sci Part A: Polym Chem 2009, 47, 5498-5508.

7 Chiu, M. Y.; Jeng, U. S.; Su, C. H.; Liang, K. S.; Wei, K. H. Adv Mater 2008, 20, 2573-2578.

8 Mihailetchi, V. D.; Xie, H.; de Boer, B.; Koster, L. J. A.; Blom, P. W. M. Adv Funct Mater 2006, 16, 699-708.

9 Li, G.; Shrotriya, V.; Huang, J.; Yao, Y.; Moriarty, T.; Emery, K.; Yang, Y. Nat Mater 2005, 4, 864-868.

10 Ma, W.; Yang, C.; Gong, X.; Lee, K.; Heeger, A. J. Adv Funct Mater 2005, 15, 1617-1622.

11 Erb, T.; Zhokhavets, U.; Gobsch, G.; Raleva, S.; Stühn, B.; Schilinsky, P.; Waldauf, C.; Brabec, C. J. Adv Funct Mater 2005, 15, 1193-1196.

12 Kim, J. Y.; Lee, K.; Coates, N. E.; Moses, D.; Nguyen, T. O.; Dante, M.; Heeger, A. J. Science 2007, 317, 222-225.

13 Reyes, M. R.; Kim, K.; Carroll, D. L. Appl Phys Lett 2005, 87, 083506.

14 Chang, Y. T.; Hsu, S. L.; Chen, G. Y.; Su, M. H.; Sing, T. A.; Diau, E. W. G.; Wei, K. H. Adv Funct Mater 2008, 18, 2356-2365.

15 Chang, Y. T.; Hsu, S. L.; Su, M. H.; Wei, K. H. Adv Mater 2009, 21, 2093-2097.

16 Chang, Y. T.; Hsu, S. L.; Su, M. H.; Wei, K. H. Adv Funct Mater 2007, 17, 3326-3331.

17 Bundgaard, E.; Krebs, F. C. Sol Energy Mater Sol Cells 2007, 91, 954-985.

18 Huo, L.; Tan, Z. A.; Wang, X.; Zhou, Y.; Han, M.; Li, Y. J Polym Sci Part A: Polym Chem 2008, 46, 4038-4049.

19 Zoombelt, A. P.; Fonrodona, M.; Turbiez, M. G. R.; Wienk, M. M.; Janssen, R. A. J. J Mater Chem 2009, 19, 5336-5342. 
20 Peng, Q.; Xu, J.; Zheng, W. J Polym Sci Part A: Polym Chem 2009, 47, 3399-3408.

21 Zhang, F.; Bijleveld, J.; Perzon, E.; Tvingstedt, K.; Barrau, S.; Inganäs, O.; Andersson, M. R. J Mater Chem 2008, 18, 5468-5474.

22 Chen, M. H.; Hou, J.; Hong, Z.; Yang, G.; Sista, S.; Chen, L. M.; Yang, Y. Adv Mater 2009, 21, 4238-4242.

23 Wakim, S.; Beaupré, S.; Blouin, N.; Aich, B. R.; Rodman, S.; Gaudiana, R.; Tao, Y.; Leclerc, M. J Mater Chem 2009, 19, 5351-5358.

24 Blouin, N.; Michaud, A.; Leclerc, M. Adv Mater 2007, 19, 2295-2300.

25 Blouin, N.; Michaud, A.; Gendron, D.; Wakim, S.; Blair, E.; Plesu, R. N.; Belletête, M.; Durocher, G.; Tao, Y.; Leclerc, M. J Am Chem Soc 2008, 130, 732-742.

26 Lu, J.; Liang, F.; Drolet, N.; Ding, J.; Tao, Y.; Movileanu, R. Chem Commun 2008, 5315-5317.

27 Li, K. C.; Hsu, Y. C.; Lin, J. T.; Yang, C. C.; Wei, K. H.; Lin, H. C. J Polym Sci Part A: Polym Chem 2009, 47, 2073-2092.

28 Moulé, A. J.; Tsami, A.; Bünnagel, T. W.; Forster, M.; Kronenberg, N. M.; Scharber, M.; Koppe, M.; Morana, M.; Brabec, C. J.; Meerholz, K.; Scherf, U. Chem Mater 2008, 20, 4045-4050.

29 Mühlbacher, D.; Scharber, M.; Morana, M.; Zhu, Z.; Waller, D.; Gaudiana, R.; Brabec, C. Adv Mater 2006, 18, 2884-2889.

$30 \mathrm{Hsu}$, S. L. C.; Lin, Y. C.; Lee, R. F.; Sivakumar, C.; Chen, J. S.; Chou, W. Y. J Polym Sci Part A: Polym Chem 2009, 47, 5336-5343.

31 Wang, E.; Wang, M.; Wang, L.; Duan, C.; Zhang, J.; Cai, W.; He, C.; Wu, H.; Cao, Y. Macromolecules 2009, 42, 4410-4415.

32 Gadisa, A.; Mammo, W.; Andersson, L. M.; Admassie, S.; Zhang, F.; Andersson, M. R.; Inganäs, O. Adv Funct Mater 2007, 17, 3836-3842.

33 Gedefaw, D.; Zhou, Y.; Hellström, S.; Lindgren, L.; Andersson, L. M.; Zhang, F.; Mammo, W.; Inganäs, O.; Andersson, M. R. J Mater Chem 2009, 19, 5359-5363.

34 Ashraf, R. S.; Hoppe, H.; Shahid, M.; Gobsch, G.; Sensfuss, S.; Klemm, E. J Polym Sci Part A: Polym Chem 2006, 44, 6952-6961.

35 Becerril, H. A.; Miyaki, N.; Tang, M. L.; Mondal, R.; Sun, Y. S.; Mayer, A. C.; Parmer, J. E.; McGehee, M. D.; Bao, Z. J Mater Chem 2009, 19, 591-593.

36 Park, S. H.; Roy, A.; Beaupré, S.; Cho, S.; Coates, N.; Moon, J. S.; Moses, D.; Leclerc, M.; Lee, K.; Heeger, A. J. Nat Photonics 2009, 3, 297-303.

37 Peet, J.; Kim, J. Y.; Coates, N. E.; Ma, W. L.; Moses, D.; Heeger, A. J.; Bazan, G. C. Nat Mater 2007, 6, 497-500.

38 Zhang, M.; Tsao, H. N.; Pisula, W.; Yang, C.; Mishra, A. K.; Müllen, K. J Am Chem Soc 2007, 129, 3472-3473.
39 Coppo, P.; Turner, M. L. J Mater Chem 2005, 15, 1123-1133.

40 Huo, L.; Hou, J.; Chen, H. Y.; Zhang, S.; Jiang, Y.; Chen, T. L.; Yang, Y. Macromolecules 2009, 42, 6564-6571.

41 Wienk, M. M.; Turbiez, M.; Gilot, J.; Janssen, R. A. J. Adv Mater 2008, 20, 2556-2560.

42 Zou, Y.; Gendron, D.; Aïch, R. B.; Najari, A.; Tao, Y.; Leclerc, M. Macromolecules 2009, 42, 2891-2894.

43 Zou, Y.; Gendron, D.; Plesu, R. N.; Leclerc, M. Macromolecules 2009, 42, 6361-6365.

44 Zhou, E.; Yamakawa, S.; Tajima, K.; Yang, C.; Hashimoto, K. Chem Mater 2009, 21, 4055-4061.

45 Wallquist, O.; Lenz, R. Macromol Symp 2002, 187, 617-629.

46 Tamayo, A. B.; Walker, B.; Nguyen, T. O. J Phys Chem C 2008, 112, 11545-11551.

47 Walker, B.; Tamayo, A. B.; Dang, X. D.; Zalar, P.; Seo, J. H.; Garcia, A.; Tantiwiwat, M.; Nguyen, T. O. Adv Funct Mater 2009, 19, 3063-3069.

48 Jordens, P.; Rawson, G.; Wynberg, H. J. Chem Soc (C) 1970, 273-277.

49 Lucas, P.; Mehdi, N. E.; Ho, H. A.; Bélanger, D.; Breau, L. Synthesis 2000, 9, 1253-1258.

50 Brzezínski, J. Z.; Reynolds, J. R. Synthesis 2002, 8, 1053-1056.

51 Coppo, P.; Cupertino, D. C.; Yeates, S. G.; Turner, M. L. Macromolecules 2003, 36, 2705-2711.

52 Yao, Y.; Liang, Y.; Shrotriya, V.; Xiao, S.; Yu, L.; Yang, Y. Adv Mater 2007, 19, 3979-3983.

53 Biniek, L.; Chochos, C. L.; Leclerc, N.; Hadziioannou, G.; Kallitsis, J. K.; Bechara, R.; Lévêque, P.; Heiser, T. J Mater Chem 2009, 19, 4946-4951.

54 Pommerehne, J.; Vestweber, H.; Guss, W.; Mahrt, R. F.; Bässler, H.; Porsch, M.; Daub, J. Adv Mater 1995, 7, 551-554.

55 Soci, C.; Hwang, I. W.; Moses, D.; Zhu, Z.; Waller, D.; Gaudiana, R.; Brabec, C. J.; Heeger, A. J. Adv Funct Mater 2007, 17, 632-636.

56 Brabec, C. J.; Winder, C.; Sariciftci, N. S.; Hummelen, J. C.; Dhanabalan, A.; van Hal, P. A.; Janssen, R. A. J. Adv Funct Mater 2002, 12, 709-712.

57 Koster, L. J. A.; Mihailetchi, V. D.; Blom, P. W. M. Appl Phys Lett 2006, 88, 093511.

58 Egbe, D. A. M.; Nguyen, L. H.; Hoppe, H.; Mühlbacher, D.; Saricific, N. S. Macromol Rapid Commun 2005, 26, 1389-1394.

59 Huang, J. H.; Ho, Z. Y.; Kekuda, D.; Chang, Y.; Chu, C. W.; Ho, K. C. Nanotechnology 2009, 20, 025202.

60 Wienk, M. M.; Kroon, J. M.; Verhees, W. J. H.; Knol, J.; Hummelen, J. C.; van Hal, P. A.; Janssen, R. A. J Angew Chem Int Ed 2003, 42, 3371-3375. 